Vol 1. No 2. November 2021, e-ISSN : 2807-1808 | P-ISSN : 2807-2294

\title{
PEMBERDAYAAN LABORATORIUM DAN SIKAP SISWA DI LABORATORIUM DALAM PEMBELAJARAN SCIENCE DI SEKOLAH MENENGAH ATAS CHARITAS JAKARTA
}

\author{
BAMBANG WIDJANARKO \\ Pascasarjana PMIPA, Universitas Indraprasta PGRI, Jakarta \\ Email : Kokowidjanarko1968@gmail.com
}

\begin{abstract}
ABSTRAK
Penelitian ini bertujuan untuk mengungkapkan peberdayaan laboratorium di Sekolah Menengah Atas Charitas di kota Jakarta. Dalam penelitian ini peneliti akan mengamati kelengkapan sarana dan prasarana laboratorium, kemampuan guru dan teknis pengelolaan laboratotium sebagai variabel penelitiannya. Subjek penelitian ini adalah siswa-siswa dan guruguru Sekolah Menengah Atas Charitas yang menggunakan laboratorium Fisika, Kimia dan Biologi. Data dikumpulkan melalui angket, observasi, dan wawancara. Data dianalisis secara deskriptif. Dalam penelitian kelengkapan sarana dan prasarana laboratorium,kemampuan guru dan teknis pengelolaan laboratorium pada kategori baik. Supervisi/evaluasi yang dilakukan oleh guru pada kategori cukup. Sikap siswa terhadap pembelajaran menggunakan laboratorium pada kategori sangat baik. Faktor-faktor determinan pembelajaran menggunakan laboratorium meliputi kelengkapan sarana prasarana laboratorium, kemampuan guru dan teknis pengelolaan laboratorium.
\end{abstract}

Kata kunci: Pemberdayaan, laboratorium, Sekolah Menengah atas

\section{ABSTRACT}

This study aims to reveal the empowerment of laboratories at Charitas High School in Jakarta. In this study, researchers will observe the completeness of laboratory facilities and infrastructure, the ability of teachers and technical laboratory management as research variables. The subjects of this study were students and teachers of Charitas High School who used the Physics, Chemistry and Biology laboratories. Data were collected through questionnaires, observations, and interviews. Data were analyzed descriptively. In the research on the completeness of laboratory facilities and infrastructure, the ability of teachers and technical laboratory management in the good category. The supervision/evaluation carried out by the teacher is in the sufficient category. The students' attitude towards learning using the laboratory was in the very good category. The determinants of learning to use the laboratory include the completeness of laboratory infrastructure, the ability of teachers and technical laboratory management.

Keywords: Empowerment, laboratory, high school

\section{PENDAHULUAN}

Pendidikan di Indonesia dari tahun ke tahun selalu mengalami perubahan - perubahan yang mengacu kepada kemampuan psikomotorik siswa/peserta didik agar mampu menunjukkan skill dan kemampuan psikomotorik yang baik dalam mengarungi dunia pendidikan di Indonesia ini. Seorang guru profesional dituntut untuk memiliki berbagai kompetensi, seperti yang diamanatkan Undang-Undang RI No. 14 tahun 2005 tentang Guru dan Dosen, bahwa guru sebagai penggagas perubahan di tengah masyarakat, dituntut untuk menguasai komptensi pedagogik, kepribadian, sosial dan kompetensi profesional yang diperoleh melalui pendidikan profesi.

Oleh karena itu seorang guru memikul tanggung jawab besar terhadap pembelajaran khususnya kepada peserta didik demi meningkatkan pengetahuan dan hasil pengalaman belajarnya dengan kata lain guru tidak hanya bertindak sebagai pengajar dan pendidik saja namun harus memiliki kemampuan untuk memilih metode pembelajaran yang paling baik untuk siswa sehingga siswa dapat mengembangkan potensi yang dimilikinya secara efektif dan 
efesien. Hal ini ditegaskan kembali dalam peraturan menteri ( Permendiknas ) No 22 tahun 2006 tentang Standar Isi, prinsip pelaksanaan kurikulum di setiap satuan pendidikan menegakkan lima pilar belajar, yaitu: (1) Belajar untuk beriman dan bertakwa kepada Tuhan Yang Maha Esa; (2) Belajar untuk memahami dan menghayati; (3) Belajar untuk mampu melaksanakan dan berbuat secara efektif; (4) Belajar untuk hidup bersama dan berguna bagiorang lain; dan (5) Belajar untuk membangun dan menemukan jati diri melalui proses pembelajaran yang aktif, kreatif, efektif, dan menyenangkan.

Dalam proses pembelajaran menurut taksonomi Bloom ada 3 ( tiga ) faktor sasaran evaluasi yang meliputi aspek -aspek ; aspek kognitif ( pengetahuan ), aspek aspek ( sikap ), dan psikomotorik ( ketrampilan ). Semua proses pembelajaran di sekolah harus mengacu kepada ketiga aspek tersebut.

Menurut Peter Kline dalam Angkowo dan Kosasih (2007. 49), belajar akan efektif jika dilakukan dalam suasana menyenangkan (fun and enjoy). Maka perlu diciptakan suasana dan sistem (kondisi) belajar yang kondusif, disamping faktor lain yang akan menentukan hasil belajar siswa.. Oleh karena itu, pengajar harus dapat menciptakan sistem lingkungan proses pembelajaran yang fun and enjoy. Tetapi perlu diketahui pula bahwa sistem lingkungan ini pun dipengaruhi oleh berbagai komponen yang saling berinteraksi, antara lain, tujuan pembelajaran, bahan kajian yang disampaikan, guru, siswa, jenis kegiatan yang dikembangkan, metode serta media pembelajaran yang dipilih.

Dalam era seperti saat ini, kemampuan skill dan psikomotorik penting sekali dipahami oleh setiap siswa atau peserta didik, oleh karena itu pemerintah melalui kementrian pendidikan dan kebudayaan mengeluarkan kurikulum baru yang disebut dengan Kurikulum 2013 atau biasa disebut K-13. Inti dari kurikulum ini adalah menitik beratkan dalam proses pengajaran dan pembelajaran yang mengarah kepada keaktifan siswa-siswi/ peserta dididk itu sendiri. Hal yang sama pernah terjadi di era tahun 1980-an dimana kurikulum CBSA ( Cara belajar siswa Aktif ) mulai diterapkan . Karena kemampuan psikomotorik dan keaktifan siswa merupakan tujuan utama selain kemampuan afektif itu maka ada baiknya jika sarana penunjang untuk proses pembelajaran dalam dunia pendidikan harus dapat terlengkapi. Perpustakaan, Laboratorium, BP yang professional merupakan salah satu dari sekian banyak sarana penunjang untuk menciptakan kompetensi siswa itu sendiri.

Keberhasilan atau keunggulan dalam prestasi serta keterbakatan siswa di sekolah merupakan keterkaitan ( interplay ) antara tiga cluster yang ciri-cirinya sebagai berikut:

1. Kemampuan Umum ( kecerdasan )

2. Kreativitas

3. Motivasi atau penyatuan diri dengan tugas motivasi intrinsic

Ketiganya harus dikembangkan secara serasi dan seimbang dalam proses belajar mengajar. Disinilah pentingnya faktor pendorong atau dorongan ( press ) yang harus berasal dari diri sendiri maupun dari luar.

Hal ini sesuai dengan pendapat Sudjana ( 2002: 80 ), yang menyebutkan adatiga komponen sikap siswa yaitu : kognisi ( berkaitan dengan pengetahuan siswa tentang objek atau stimulus yang dihadapinya).afeksi ( berkaiatan dengan perasaan siswa dalam menanggapi objek tersebut ) dan konasi ( berkiatan dengan kecenderungan siswa berbuat terhadap objek tersebut) Sedangkan menurut Syah (2006: 149) sikap siswa adalah gejala internal yang berdimensi afektif berupa kecenderungan untuk mereaksi atau merespons (response tendency) dengan cara yang relatif tetap terhadap objek orang, barang, dan sebagainya, baik secara positif maupun negative dan menurut Nana Syaodih (2011: 155), mengatakan bahwa belajar merupakan perubahan dalam kepribadian yang ditampilakan sebagai pola-pola respons yang baru dalam bentuk keterampilan, sikap, kebiasaan, pengetahuan, dan kecakapan”.

Kita juga dapat melihat kreatifitas itu sebagai suatu proses, dimana yang diutamakan ialah " bersibuk diri " seacara kreatif. Pada anak yang masih dalam proses pertumbuhan hendaknya kreatifitas sebagai proses yang perlu mendapat perhatian, bahwa ia sibuk dan senang berkreasi. Guru berperan sebagai fasilitatator yang mendorong siswa/siswi belajar mandiri sebanyak 
mungkin, dapat menerima gagasn-gagasan dari siswa, dapat menerima perbedaan antar siswa dalam kemampuan siswa untuk memberikan gagasan atau ide-ide baru. Khusus untuk pembelajaran Science ( Fisika, Kimia dan Biologi ), pembentukan kreatifitas, ide-ide yang menarik, gagasan- gagasan yang menantang serta menerima perbedaan dalam diskusi atau dalam presentasi di depan kelas sangat lah di mungkinkan terjadi dengan baik;

Kesemua faktor diatas dapat dilakukan jika sarana dan prasarana sekolah dapat berjalan secara sinergi. Salah satu sarana agar siswa dapat belajar maniru dan dapat menerima gagasangagasan dari siswa lain serta dapat memberikan ide-ide baru serta menerima perbedaan adalah dengan mengunakan laboratorium. Dalam laboratorium, siswa bekerja bersama dalam kelompoknya untuk melakukan suatu percobaan atau experiment yang kemudian hasilnya dapat di presentasikan di kelas. Menurut Hasruddin dan Rezeqi (2012), dalam proses belajar dan mengajar, perhatian siswa terhadap materi yang diberikan oleh guru sangat mempengaruhi berhasil atau tidaknya proses belajar mengajar tersebut.

Menurut pandangan Kertiasa (2006: 1) dikatakan bahwa laboratorium adalah tempat bekerja untuk mengadakan percobaan atau penyelidikan dalam bidang ilmu tertentu seperti IPA, tekhnik dan sebagainya. Dalam pengertian terbatas laboratorium adalah suatu ruangan tertutup dimana percobaan dan penelitian dilakukan, tempat ini dapat merupakan suatu ruangan tertutup, kamar atau ruangan terbuka, Dalam pengkatagoriannya Departement Pendidikan dan Kebudayaan Republik Indonesia (Depdikbud, 1995: 7) mengkatagorikan laboratorium di sekolah menengah sebagai laboratorium dasar dan laboratorium pengembangan. serta dalam pengelolaannya diatur dalam Pedoman Pendayagunaan Laboratorium dan Alat Pendidikan IPA Departemen Pendidikan Nasional (1995). Dalam pengelolaan laboratorium meliputi beberapa apek yaitu : perencanaan, pengorganisasian, pelaksanaan, persyaratan tata letak, kelengkapan sarana, admistrasi dan pengevaluasian. Jadi selain secara fisik laboratorium, peran guru sebagai pengelola sangat besar. Dalam hal ini kemampuan atau kompetensi guru yang di harapkan dalam pembelajaran di laboratorium yang di maksudkan adalah kemampuan individual dalam merencanakan, mengorganisaikan, melaksanakan dan mengevaluasi semua kegitan yang berhubungan dengan proses pembelajaran di laboratorium. Sikap siswa juga turut memegang peran penting dalam berlangsungnya proses pembelajaran di laboratorium.

Selama ini pembelajaran Science di Sekolah Menegah Atas selalu menggunakan metode pembelajaran secara konvensional, maksudnya adalah selama ini pembelajaran Science untuk siswa Sekolah Menengah Atas diharuskan untuk mendengar, melatih dan menghitung angka angka dan persamaan, serta cenderung ke arah pembahasan teori yang bersifat khusus (tematik teoritik) dan berdasarkan materi yang ada di dalam buku (text book oriented) sehingga hasil belajar yang diperoleh kurang memuaskan. Di tambah dengan kemampuan dan keingian guru untuk membawa siswa ke laboratorium yang sangat rendah. Banyak Siswa Sekolah Menegah Atas mengalami kesulitan untuk mencerna dan tidak dapat mengembangkan interaksi dengan sesamanya sebagai latihan hidup di masyarakat. Di sekolah siswa hanya memperoleh pelatihan teori dengan tingkat pemahaman yang rendah karena terlalu banyak hitungan. Siswa hanya tahu bahwa tugasnya adalah mengenal fakta teoritis, sementara pemahaman dan mengembangkan interaksi belum dapat mereka kuasai. Masalah yang sama juga terjadi di sekolah kami, Sekolah Menengah Atas Charitas Jakarta.

Untuk mengatasi permasalahan tersebut maka peneliti akan mencoba menggunakan metode yang dapat menambah daya tarik belajar siswa khususnya dalam mata pelajaran Science (Fisika, Kima dan Bioloi) dan mudah dipahami siswa Sekolah Menegah Atas. Metode yang digunakan oleh peneliti ialah pemberdayaan laboratorium di Sekolah Menengah Atas.

Dengan pemberdayaan laboratorium untuk pembelajaran Science ini peneliti fokuskan untuk mata pelajaran Fisika, Kimia dan Biologi, sehingga dapat membantu guru dalam mengembangkan materi pelajaran masing-masing, dan pada akhirnya siswa lebih tertarik dalam belajar. Melalui pemberdayaan laboratorium Science siswa juga dapat lebih cepat dalam memahami materi yang disajikan oleh guru. 


\section{METODE PENELITIAN}

Pada penelitian ini menggunakan teknik analisis deskriptif kualitatif, yaitu suatu metode penelitian dengan instrumen teknik pengumpulan data dilakukan secara trigulasi (gabungan), analisis data bersifat induktif/kualitatif, dan hasil penelitian kualitatif lebih menekankan makna daripada generalisasi. Penelitian deskriptif kualitatif bertujuan untuk menggambarkan, melukiskan, menerangkan,menjelaskan dan menjawab secara lebih rinci permasalahan yang akan diteliti dengan mempelajari semaksimal mungkin seorang individu, suatu kelompok atau suatu kejadian. Dalam penelitian kualitatifmanusia merupakan instrumen penelitian dan hasil penulisannya berupakata-kata atau pernyataan yang sesuai dengan keadaan sebenarnya dan bersifat menggambarkan kenyataan atau fakta sesuai dengan data angka-angka yang diperoleh dengan tujuan untuk mengetahui peningkatan hasil belajar yang dicapai peserta didik juga untuk memperoleh respon aktivitas peserta didik selama proses pembelajaran dengan mengunakan laboratorium..

Populasi penelitian ini terdiri dari : seluruh siswa-siswi SMA Charitas Jakarta jurusan IPA.Data diambil dengan cara purposive sampel dan cara cluster proportional random sampel untuk mengungkapkan sikap siswa Subjek yang diteliti adalah tiga kelas yaitu kelas 10 ipa-1, 11 ipa-2 dan 12 ipa-1 sebnayak 107 siswa dan reponden kepala sekolah (1 orang), guru IPA (3 orang) serta koordinator laboratorium (1 orang)

Dalam penelitian ini, variabel penelitian sikap siswa menggunakan tabel Krejckie dari jumlah keseluruhan 107 siswa sampel yang digunakan sebanyak 60 siswa dan variabel penelitian kemampuan guru berupa kemampuan manajerial dan kemampuan individual, kelengkapan sarana dan prasarana laboratorium dan teknis pengelolaan laboratorium mengunakan 5 responden yang terdiri dari kepala sekolah , 3 orang guru dan 1 orang koordinator laboratorium. Pengambilan data penelitian sikap siswa, kemampuan guru berupa kemampuan manajerial dan kemampuan individual, kelengkapan sarana dan prasarana laboratorium dan teknis pengelolaan laboratorium dilakukan pada semester ganjil tahun $2017 / 2018$.

\section{HASIL DAN PEMBAHASAN}

Pemberdayaan laboratorium IPA dalam pembelajaran Science akan dapat meningkatkan keberhasilan kegiatan pembelajaran IPA di SMA Charitas Jakarta. Dalam pemberdayaan laboratorium IPA di SMA Charitas Jakarta melibatkan beberapa aspek-aspek, yaitu kemampuan guru dalam menggunakan alat dan bahan, ketersediaan/kelengkapan sarana prasarana laboratorium dan teknis pengelolaan yang efektif. Pemberdayaan laboratorium juga akan berjalan baik jika didukung oleh sikap/penerimaan siswa yang baik terhadap pola pembelajaran IPA di SMA Charitas dalam menggunakan laboratorium.

\section{Sikap Siswa terhadap Pembelajaran IPA Menggunakan Laboratorium}

Berdasarkan hasil analisis data dari 60 siswa didapatkan data sebagai berikut : sikap siswa mempunyai rentang skor 10 , yaitu tertinggi 70 dan terendah 45 . Rerata 64,25, mode 63 , median 61,30 dan standar deviasi 6,096.

Tabel 1. Distribusi Frekuensi Skor Sikap Siswa

\begin{tabular}{|c|c|c|c|c|}
\hline No & Rentang Skor & Kategori & Frekuensi & Persen \\
\hline 1 & $60<X$ & Sangat baik & 33 & 55.00 \\
\hline 2 & $50<X \leq 60$ & Baik & 17 & 28.33 \\
\hline 3 & $40<X \leq 50$ & Cukup & 10 & 16.67 \\
\hline 4 & $30<\mathrm{X} \leq 40$ & Kurang & & \\
\hline 5 & $X \leq 30$ & Sangat kurang & & \\
\hline & & Jumlah & 60 & 100 \\
\hline
\end{tabular}


Hasil analisis sikap siswa terhadap pembelajaran IPA menggunakan laboratorium memiliki rerata 77,65 berada pada kategori sangat baik dengan persentase 68,29. Dengan dukungan 68,,29\% diharapkan kegiatan pembelajaran IPA menggunakan laboratorium dapat berjalan dengan baik, karena penerimaan siswa yang sangat baik.

\section{Kelengkapan Sarana Prasarana Laboratorium}

Berdasarkan hasil analisis data dari 5 responden (kepala sekolah, guru dan kepala laboratorium) didapatkan data sebagai berikut : kelengkapan sarana prasarana mempunyai rentang skor 10, yaitu tertinggi 75 dan terendah 44. Rerata 58, mode 57, median 59,50 dan standar deviasi 6,102.

\section{Tabel 2. Distribusi Frekuensi Kelengkapan Sarana Prasarana Laboratorium}

\begin{tabular}{|l|l|l|l|l|}
\hline No & Rentang Skor & Kategori & Frekuensi & Persen \\
\hline 1 & $60<\mathrm{X}$ & Sangat baik & 1 & 20.00 \\
\hline 2 & $50<\mathrm{X} \leq 60$ & Baik & 3 & 60.00 \\
\hline 3 & $40<\mathrm{X} \leq 50$ & Cukup & 1 & 20.00 \\
\hline 4 & $30<\mathrm{X} \leq 40$ & Kurang & & \\
\hline 5 & $\mathrm{X} \leq 30$ & Sangat kurang & & \\
\hline & & Jumlah & 5 & 100 \\
\hline
\end{tabular}

Hasil analisis penilaian terhadap kelengkapan sarana prasana laboratorium dalam mendukung kegiatan praktikum diperoleh rerata 58,00 yang berada dalam kategori baik. Dari 3 laboratorium sebagai responden, perabot yang bersifat tetap dan permanen memperoleh persentase ketercapaian antara 90-95\%. Artinya untuk kelengkapan perabot yang bersifat tetap dan permanen masuk dalam kategori sangat baik Luas ruang laboratorium siswa yang dimiliki oleh ketiga laboratorium rata-rata berukuran $12 \times 12 \mathrm{~m} 2$ dengan jumlah siswa sekitar $25-30$ siswa perkelas, atau sekitar 4,3 - 5,1 untuk ruang gerak siswa.

Tiga laboratorium yang ada masih sudah merupakan merupakan laboratorium mandiri yang terdiri dari laboratorium Biologi, laboratorium Kimia dan laboratorium Fisika.Selain ruangan untuk melakukan praktikum, setiap laboratorium juga memiliki ruang persiapan dan penyimpanan yang berfunsi sebagai ruang penyimpanan alat/bahan dan penyimpanan kelengkapan admistrasi laboratorium.

Perlengkapan penunjang dan sarana pengamanan keselamatan memiliki ketercapaian 70\%. Sarana pengamanan keselamatan, setiap laboratorium telah memiliki alat pemadam kebakaran yang dapat digunakan dan selalu dicek ke pihak yang berwenang. Keadaan ruangan yang meliputi kebersihan, kerapian dan kemudahan untuk mengambil alat dan bahan dari empat responden memiliki ketercapaian $90 \%$. Kelengkapan sarana berada pada posisi kurang pada pemeliharaan alat dan bahan yang memperoleh skor 5\%, hal ini disebabkan karena beberapa bahan merupakan bahan habis terpakai (habis pakai).

Teknisi untuk melakukan perawatan dan perbaikan alat tidak dimiliki oleh keempat responden (guru dan kepala laboratorium), sehingga berdasarkan pengamatan beberapa alat yang rusak tidak dilakukan reparasi tetapi dikumpulkan menjadi satu di tempat tertentu. Peralatan audio visual dan elektronika yang mendukung kegiatan pembelajaran di laboratorium seperti komputer dan LCD memperoleh persentase 95\%, karena ketersediaan alat-alat tersebut memang ada dengan penyimpanan di dalam laboratorium .

Untuk kelengkapan administrasi, keempat responden telah melakukan pengadministrasian dengan ketercapaian $85 \%$, hal ini ditunjukkan dengan buku inventaris dan buku acuan pengelolaan yang tercatat rapi. Untuk pencatatan alat rusak yang ditunjukkan oleh adanya catatan dan kartu reparasi menunjukkan berada pada kategori yang sangat kurang dengan persentase $20 \%$, artinya dari keempat responden tidak melakukan aktivitas reparasi alat. Pencatatan persediaan dalam buku stok menunjukkan kategori cukup dengan persentase 55\%. 
Secara umum kelengkapan sarana dan prasarana laboratorium menunjukkan baik, dengan prosentase $75 \%$.

\section{Kemampuan Guru Menggunakan Laboratorium}

Berdasarkan hasil analisis data dari 3 guru IPA sebagai responden didapatkan data sebagai berikut : kemampuan guru menggunakan laboratorium mempunyai rentang skor, yaitu tertinggi 89 dan terendah 58. Rerata 95,03, mode 84, median 74,05 dan standar deviasi 5,931.

Tabel 3. Distribusi Frekuensi Kemampuan Guru

\begin{tabular}{|l|l|l|l|l|}
\hline No & Rentang Skor & Kategori & Frekuensi & Persen \\
\hline 1 & $60<\mathrm{X}$ & Sangat baik & 2 & 67.66 \\
\hline 2 & $50<\mathrm{X} \leq 60$ & Baik & 1 & 32.34 \\
\hline 3 & $40<\mathrm{X} \leq 50$ & Cukup & & \\
\hline 4 & $30<\mathrm{X} \leq 40$ & Kurang & & \\
\hline 5 & $\mathrm{X} \leq 30$ & Sangat kurang & & \\
\hline & & Jumlah & 3 & 100 \\
\hline
\end{tabular}

Hasil analis penilaian terhadap kemampuan guru diperoleh rerata 95,03 berada dalam kategori sangat baik. Hasil ini membuktikan bahwa kemampuan guru melakukan pembelajaran di laboratorium sangat baik. Dalam mempersiapkan dan melaksanakan tugas termasuk pengorganisasian waktu dan ruang, guru telah melakukan dengan baik dengan tingkat ketercapaian antara 80,2 - 100\%. Namun dalam membimbing siswa mengumpulkan dan mencatat data serta membimbing siswa melakukan pengamatan suatu proses memperoleh persentase 61,2 - 70, belum mencapai hasil yang optimal jika dibandingkan dengan persiapan. Berdasarkan pengamatan di lapangan, dari 3 orang responden menunjukkan bahwa keterampilan guru menggunakan peralatan pada saat melakukan demonstrasi, berada pada kemampuan baik.Dari pengamatan dilapangan didapatkan bahwa semua guru menunjukkan metode mengajar yang sama, yaitu melakukan demonstrasi terlebih dahulu sebelum mengajak siswa untuk melakukan percobaan sendiri setelah itu baru menerapkan pendekatan ketrampilan proses dengan melibatkan siswa secara penuh dalam melakukan percobaan, mengamati percobaan dan mencatat hasil percobaan. Secara umum kemampuan guru melakukan pembelajaran Science di laboratorium menunjukkan baik, dengan prosentase $78 \%$.

\section{Teknis Pengelolaan Laboratorium}

Berdasarkan hasil analisis data dari 4 responden ( guru dan kepala laboratorium ) didapatkan data sebagai berikut : kelengkapan sarana prasarana mempunyai rentang skor 10 , yaitu tertinggi 85 dan terendah 58. Rerata 81, mode 71, median 75,50 dan standar deviasi 5,112.

Tabel 4. Distribusi Frekuensi Teknis Pengelolaan Laboratorium

\begin{tabular}{|l|l|l|l|l|}
\hline No & Rentang Skor & Kategori & Frekuensi & Persentase \\
\hline 1 & $60<\mathrm{X}$ & sangat baik & 3 & 75.00 \\
\hline 2 & $50<\mathrm{X} \leq 60$ & baik & 1 & 25.00 \\
\hline 3 & $40<\mathrm{X} \leq 50$ & cukup & & \\
\hline 4 & $30<\mathrm{X} \leq 40$ & kurang & & \\
\hline 5 & $\mathrm{X} \leq 30$ & sangat kurang & & \\
\hline & & Jumlah & 4 & 100 \\
\hline
\end{tabular}

Dalam pengolahan data untuk tekhnik pengelolaan laboratorium, data diambil dari dua pendapat dengan obyek yang sama. Hal ini dilakukan karena kegiatan yang dilakukan oleh guru merupakan tugas rangkap sebagai guru dan laboran. Teknis pengelolaan laboratorium oleh guru dan koordinator laboratorium apabila dirangkum maka jumlah responden menjadi sebanyak 4 
responden memperoleh persentase skor perencanaan sebesar 67\% dengan kategori sangat baik, pengorganisasian memperoleh persentase skor sebesar 57\% dengan kategori baik, pelaksanaan memperoleh persentase skor sebesar 60\% dengan kategori baik dan supervisi/evaluasi memperoleh persentase skor 53\% dengan kategori baik. Hasil analisis teknis pengelolaan laboratorium secara keseluruhan yang dilakukan guru sebagai pembimbing/laboran dan koordinator laboratorium memiliki rerata 76,20 berada pada kategori baik. Secara umum kemampuan guru dalam tekhnik pengelolaan laboratorium menunjukkan baik, dengan prosentase $78 \%$.

Dari faktor kemampuan guru menunjukkan kategori baik dengan persentase $78 \%$, faktor kelengkapan sarana prasarana menunjukkan kategori baik dengan persentase $75 \%$, keefektifan pengelolaan laboratorium menunjukkan kategori baik dengan persentase $73 \%$ dan dukungan siswa terhadap pembelajaran menggunakan laboratorium menunjukkan kategori sangat baik dengan persentase 68,29 \%, maka pemanfaatan laboratorium IPA di SMA Charitas Jakarta dapat dikatakan efektif dengan kategori baik. Hal ini juga didukung oleh hasil observasi yang menunjukkan bahwa frekuensi pelaksanaan praktikum sudah menunjukkan ketercapaian $100 \%$ antara rencana dan pelaksanaannya dalam 1 semester di SMA Charitas Jakarta, serta terlaksananya praktikum sebanyak 1 kali dalam 1 bulan

Berdasarkan uji penelitian, diperoleh hasil bahwa pemberdayaan laboratorium IPA memiliki suatu korelasi yang signifikan terhadap hasil belajar IPA siswa SMA Charitas Jakarta.. Hal ini dapat dilihat dari hasil uji korelasi dengan nilai Sig. 0,03 $<0,05$ menunjukkan adanya hubungan antara pemberdayaan laboratorium IPA dengan hasil belajar Science di SMA Charitas. Untuk koefisien korelasi, diperoleh nilai sebesar 0,276 dan berdasarkan interpretasi SPSS, maka dapat disimpulkan bahwa tingkat hubungan antara pemberdayaan laboratorium IPA dengan hasil belajar adalah cukup baik dengan arah korelasi positif karena nilai koefisien positif.

Faktor adanya hubungan antara pemanfaatan laboratorium dengan hasil belajar dapat dipengaruhi oleh optimalnya dalam memanfaatkan laboratorium secara keseluruhan baik pada sarana maupun prasarana, dan hasil belajar siswa yang cenderung bernilai naik . Hal ini dperkuat dari hasil wawancara dengan guru yang berpendapat bahwa dengan adanya kegiatan praktikum siswa menjadi lebih tahu bentuk benda yang di bicarakan sekalipun adanya hambatan dari siswa ketika melaksanakan pembelajaran di laboratorium. Selain itu, faktor hipotesis diterima juga dipengaruhi oleh data sampel yang berhasil membuktikan hubungan tersebut. Pengambilan sampel yang terlalu sedikit dapat mempengaruhi tidak adanya korelasi antar variabel. Dalam penelitian ini hanya menggunakan sampel dari tiga kelas dengan jumlah 60 siswa. Sehingga hal ini dapat mempengaruhi kategori interpretasi korelasi pemanfaatan laboratorium IPA dan hasil belajar adalah cukup baik.

Dari hasil belajar yang didapat setelah melakukan praktikum, diperoleh rata-rata nilai keseluruhan siswa adalah 78,8. Hasil belajar mereka tergolong tinggi dibuktikan dengan 79,8\% siswa kelas X IPA , mencapai nilai baik. Sedangkan untuk kelas XI IPA diperoleh 70,4 \% siswa memiliki nilai baik. Sedangkan untuk kelas XII IPA diperoleh 77,5\% siswa memiliki nilai baik.

Berdasarkan dari hasil wawancara yang dilakukan pada guru mata pelajaran IPA, dari hasil belajar yang dimiliki oleh siswa dalam pelajaran IPA baik didalam kelas dengan metode ceramah dibandingkan hasil belajar yang dimiliki siswa dalam pelajaran IPA di laboratorium, di SMA Charitas menunjukkan adanya perbedaan yang signifikan atau tinggi dalam hasil belajar siswa SMA Charitas Jakarta. Nilai siswa ketika dilakukan praktikum, akan lebih meningkat dibandingkan saat kegiatan belajar mengajar didalam kelas. Hal ini makin memperkuat dan mendukung pendapat para ahli bahwa mata pelajaran IPA yang merupakan kelompok fisika, kimia dan biologi pada hakikatnya adalah produk, proses, sikap, dan teknologi.Pembelajaran IPA sangat erat kaitannya dengan kegiatan praktek, yang dilakukan di laboratorium (Sagala, 2010). Laboratorium diharapkan dapat menunjang proses belajar mengajar agar tercapai tujuan pembelajaran, sehingga upaya meningkatkan prestasi siswa semakin meningkat. Praktikum merupakan salah satu kegiatan laboratorium yang sangat 
berperan dalam menunjang keberhasilan proses belajar mengajar IPA (Harefa, 2017). Laboratorium adalah tempat pengamatan, percobaan, latihan dan pengujian konsep pengetahuan dan teknologi. (Harefa, D., Ndruru, M., Ndraha, L., 2020). Agar laboratorium IPA disekolah dapat berperan, berfungsi dan bermanfaat seperti itu, maka diperlukan sebuah system pengelolaan laboratorium yang direncanakan dan dievaluasi dengan baik serta dilaksanakan oleh semua pihak yang terkait dengan penyelenggaraan laboratorium IPA di sekolah yang bersangkutan (Harefa, 2018). Hasil penelitian (Yurnan, 2010), menyatakan bahwa pemanfaatan laboratorium IPA berkolerasi positif dengan hasil belajar

Pemanfaatan laboratorium oleh guru mata pelajaran IPA dalam kegiatan praktikum di SMA Charitas dinilai sudah cukup optimal. Hal ini berdasarkan hasil wawancara dengan guru IPA yang mengatakan bahwa guru menggunakan laboratorium secara optimal dan memanfaatkan sarana laboratorium sesuai dengan kebutuhan dan petunjuk praktikum. Dalam melaksanakan kegiatan praktikum, guru IPA dan pengelola laboratorium akan berdiskusi terlebih dahulu mengenai materi yang akan dipraktikumkan dan melakukan persiapan alat dan bahan yang akan digunakan dalam praktikum.

Dari penjelasan diatas menunjukkan bahwa pemberdayaan laboratorium dalam pembelajaran science dapat meningkatkan hasil belajar IPA di SMA Charitas Jakarta, namun perlu dilakukan pembenahan dalam pelaksanaan praktikum, sehingga setiap praktikum bermanfaat bagi siswa dalam menunjang pemahamannya terhadap materi pelajaran.

Beberapa faktor yang dapat mempengaruhi hasil belajar siswa di dalam laboratorium adalah sebagai berikut :

1. Kurang kondusifnya keadaan siswa ketika didalam laboratorium dan kurang termotivasinya siswa dalam belajar materi IPA.

2. Kurangnya perhatian dari guru terhadap siswa yang belum memahami mengenai teori yang diajarkan.

3. Keaktifan siswa dalam melaksanakan praktikum juga akan mempengaruhi hasil belajar yang dicapai. Siswa yang tidak aktif bertanya atau tidak fokus pada kegiatan praktikum atau pembelajaran, akan cenderung lebih sulit memahami suatu materi.

4. Faktor lainnya yang dapat mempengaruhi hasil belajar siswa menjadi rendah yakni faktor sosial seperti adanya keributan terjadi didalam kelas yang disebabkan oleh teman siswa lain. Hal ini akan mempengaruhi suasana belajar siswa sehingga dapat mengganggu konsentrasi siswa dalam memahami dan menerima materi yang disampaikan oleh guru.

Umumnya, guru disekolah ketika melaksanakan praktikum tidak didampingi oleh laboran, sehingga guru harus berperan sebagai seorang guru dan juga sebagai laboran. Hal ini dapat menuntut seorang guru memiliki kreativitas dan kemampuan dalam mengelola atau memanfaatkan laboratorium serta kemauan memberdayakan pembelajaran di laboratorium. Kondisi dan penggunaan fasilitas di laboratorium sangat penting diperhatikan agar siswa termotivasi dalam belajar sehingga membantu meningkatkan hasil belajar siswa. Pengawasan dari guru terhadap aktivitas siswa di laboratorium juga diperlukan agar kegiatan pembelajaran dilaboratorium dapat berjalan dengan kondusif. Selain itu, lingkungan belajar yang kondusif juga akan memberikan pengaruh terhadap hasil belajar yang didapatkan siswa. Dengan begitu, pemberdayaan laboratorium IPA dalam permbelajaran Science akan memberikan hasil belajar yang baik.

\section{KESIMPULAN}

Seorang guru memikul tanggung jawab besar terhadap pembelajaran khususnya kepada peserta didik demi meningkatkan pengetahuan dan hasil pengalaman belajarnya dengan kata lain guru tidak hanya bertindak sebagai pengajar dan pendidik saja namun harus memiliki kemampuan untuk memilih metode pembelajaran yang paling baik untuk siswa sehingga siswa dapat mengembangkan potensi yang dimilikinya secara efektif dan efesien.Oleh karena itu, pengajar harus dapat menciptakan sistem lingkungan proses pembelajaran yang fun and enjoy. 
Tetapi perlu diketahui pula bahwa sistem lingkungan ini pun dipengaruhi oleh berbagai komponen yang saling berinteraksi, antara lain, tujuan pembelajaran, bahan kajian yang disampaikan, guru, siswa, jenis kegiatan yang dikembangkan, metode serta media pembelajaran yang dipilih.

Salah satu metode yang di terapkan untuk menciptakan suasana yang menyenangkan dalam belajar adalah pemberdayaan laboratorium, terutama untuk mata pelajaran IPA.Dalam pengelolaan laboratorium meliputi beberapa apek yaitu : perencanaan, pengorganisasian, pelaksanaan , persyaratan tata letak ,kelengkapan sarana , admistrasi dan pengevaluasian. Jadi selain secara fisik laboratorium, peran guru sebagai pengelola sangat besar. Dalam hal ini kemampuan atau kompetensi guru yang di harapkan dalam pembelajaran di laboratorium yang di maksudkan adalah kemampuan individual dalam merencanakan, mengorganisaikan, melaksanakan dan mengevaluasi semua kegitan yang berhubungan dengan proses pembelajaran di laboratorium.

Dari hasil analisis penelitian diperoleh bahwa faktor kemampuan guru, faktor kelengkapan sarana prasarana, keefektifan pengelolaan laboratorium menunjukkan kategori baik, sedangkan dukungan siswa terhadap pembelajaran menggunakan laboratorium menunjukkan kategori sangat baik. Dengan demikian, dari ketiga faktor determinan yang menunjukkan kategori baik dan dukungan siswa menunjukkan kategori sangat baik, maka pemberdayaan laboratorium dalam pembelajaran Science di SMA Charitas Jakarta dapat dikatakan efektif dengan kategori baik.

\section{DAFTAR PUSTAKA}

Angkowo R. dan A. Kosasih. (2007). Optimalisasi Media Pembelajaran. Jakarta : PT. Grasindo

Badan Standar Nasional Pendidikan. (2006). Standar Sarana dan Prasarana Sekolah/Madrasah Pendidikan Umum. Jakarta.

Harefa, D. (2017). Pengaruh Presepsi Siswa Mengenai Kompetensi Pedagogik Guru Dan Minatbelajar Siswa Terhadap Prestasi Belajar Ilmu Pengetahuan Alam (Survey pada SMK Swasta di Wilayah Jakarta Utara). Horison Jurnal Ilmu Pendidikan Dan Lingusitik, 7(2), 49-73.

Harefa, D. (2020). Peningkatan Prestasi Rasa Percaya Diri Dan Motivasi Terhadap Kinerja Guru IPA. Media Bina Ilmiah, 13(10), 1773-1786. https://doi.org/https://doi.org/10.33758/mbi.

Hasrudin dan Resqi. (2012) Analisis Pelaksanaan Praktikum Biologi dan Permasalahan di SMA Negeri Sekabupaten Karo. Jurnal Tabularasa PPS UNIMED: 9 (1) : 17-32 8

Kementrian pendidikan Menengah Umum dan tinggi, Direktorat Jenderal Pendidikan Menengah Tinggi 2005 :. Undang-Undang RI No. 14 tahun 2005 tentang Guru dan Dosen Jakarta: Departement pendidikan dan Kebudayaan Republik Indonesia.

Kementrian pendidikan dasar dan menengah Direktorat Jenderal Pendidikan Menengah Umum 2006. Peraturan menteri (Permendiknas) No 22 tahun 2006 Jakarta: Departement pendidikan dan Kebudayaan Republik Indonesia

Nana Sudjana. (2002). Penilaian hasil proses belajar mengajar. Bandung: Remaja Rosda Karya.

Nana Syaodik. (2011). Pengelolaan Laboratorium IPA. Makalah. Disampaikan pada Technical Assistance Pengelolaan Laboratorium IPA. Jakarta

Novianti, N.R. (2011). Kontribusi Pengelolaan Laboratorium. Jurnal Pendidikan Indonesia ISSN: 2303-288X Vol. 3, No. 2, Oktober 2014.

Novianti, N.R. (2011). Motivasi Belajar Siswa Tehadap Efektifitas Proses Pembelajaran (Penelitian pada SMP Negeri dan Swasta di Kabupaten Kuningan Provinsi Jawa Barat). Jurnal.Upi.Edu/File/15. Edisi Khusus No. 1, Agustus 2011. ISSN 1412-565X Nyoman Kertiasa. (2006). Laboratorium sekolah dan pengelolaannya. Jakarta: Pudak Scientific.

PP Nomor 19 Tahun 2005 tentang Standar Nasional Pendidikan. Depdiknas. 
Pusat Kurikulum. (2013). Kurikulum berbasis kompetensi (K-13). Jakarta: Balitbang Depdiknas.

Sagala. (2010). Konsep dan Makna Pembelajaran. Alfabeta.

Sidharta, A., dkk. (2007). Studi Penelusuran Kinerja Laboratorium Sebagai Analisis Keefektifan Pengelolaan Laboratorium IPA LPMP. Pusat Pengembangan dan Pemberdayaan Pendidik dan Tenaga Kependidikan Ilmu Pengetahuan Alam. Bandung.

Subamia, I.D.P, dkk. (2012). Pelatihan Keterampilan Dasar Laboratorium (Basic Skill Laboratory) Bagi Staf Laboraorium IPA SMP SeKabupaten Buleleng. Jurnal Pengabdian Kepada Masyarakat Widya Laksana. Undiksha: ISSN: 1410-4369, Edisi Juli 2012.

Sulastri, S. (2008). Identifikasi Kondisi Laboratorium IPA dan Penggunaannya di SMP Negeri di Wilayah Jakarta Selatan. Jurnal Lingkar Mutu Pendidikan. Volume I.

Syah, M. (2006). Psikologi belajar. Jakarta: PT. Radja Grafindo Persada.

Yurnan. (2010). Pemanfaatan Laboratorium Untuk Meningkatkan Hasil Belajar IPA. Jurnal Tabularasa PPS Unimed, 7, 95-104. 